\title{
Monetary Policy, Cash Flow and Corporate Investment: Empirical Evidence from Vietnam
}

\author{
Linh My Tran ${ }^{1, *(1)}$, Chi Hong Mai ${ }^{1}$, Phuoc Huu Le ${ }^{2}$, Chi Linh Vu Bui ${ }^{3}{ }^{(1)}$, \\ Linh Viet Phuong Nguyen ${ }^{4}$ (i) and Toan Luu Duc Huynh ${ }^{5}$ (B) \\ 1 Faculty of Accounting and Auditing, Banking University of Ho Chi Minh City, Ho Chi Minh City 700000, \\ Vietnam; chimh@buh.edu.vn \\ 2 English Faculty, Foreign Trade University, Ho Chi Minh City 700000, Vietnam; lehuuphuoc.cs2@ftu.edu.vn \\ 3 Faculty of Business Administration, Banking University of Ho Chi Minh City, Ho Chi Minh City 700000, \\ Vietnam; linhchinh179@gmail.com \\ 4 Faculty of Finance, Banking University of Ho Chi Minh City, Ho Chi Minh City 700000, Vietnam; \\ linhngo2998@gmail.com \\ 5 School of Banking, University of Economics Ho Chi Minh City, Ho Chi Minh City 700000, Vietnam; \\ toanhld@ueh.edu.vn \\ * Correspondence: linhtm0909@gmail.com
}

Received: 7 February 2019; Accepted: 13 March 2019; Published: 19 March 2019

\begin{abstract}
This paper examines the relationships between macroscopic determinants (typically, monetary policies) and microscopic factors (mainly, cash flows and other controlling variables) on corporate investment. By employing system-GMM estimation for the 250 Vietnamese non-financial firms, the authors find that the expansionary monetary policy not only encourages the borrowing activities but also results in more corporate investment activities over the period from 2006 to 2016. Noticeably, the internal cash flow is also significant factor, which enhances the activities of corporate investment. Finally, there are differences between internal cash flow effects on corporate investments between two groups, divided by three theoretical criteria. To recapitulate, our implications highlight the importance of monetary policy stability for sustainable growth in corporate investment in Vietnam.
\end{abstract}

Keywords: monetary policy; cash flow; investment; GMM

JEL Classification: E52; M21; D92

\section{Introduction}

Monetary policy (MP) is one of the most significant macroeconomic policies in the market economy, which directly affects monetary circulation, contributing to promoting activities in the economy, in which investment is the most important. These policies, which are controlled by the State Bank of Vietnam (SBV), are measures to influence money supply, thereby impacting the market interest. Monetary policies are supposed to have substantial impacts on corporate lending (Kashyap et al. 1993) and corporate investment (Morck et al. 2013).

According to money supply statistics from World Bank, the money supply in Vietnam has increased continuously in recent years, which is the result of Central Bank's expansionary money policy. Our question is whether the level of investment in Vietnam is proportional to the level of the money supply of SBV—in other words-whether it increases as SBV applies expansionary monetary policy. In this research, the authors focus on measuring the impacts of monetary policy on corporate investment decisions in Vietnam, comparing the impacts of macroeconomic policies with the impacts of internal factors (amount of holdings, cash flow, business scale, financial leverage, etc.). Especially, one 
of main reasons to choose Vietnam as country research is that Vietnam is becoming the standing-out element among emerging markets (Bloomberg 2016). Moreover, Batten and Vo (2014, 2015) also emphasized that Vietnamese stock markets have typical characteristics such as (i) the significant participant of foreign ownership (ii) liquidity and (iii) institutional control.

The sensitivity of the corporate investment to the change in monetary policy depends on the financial capacities of the business and its dependence on internal funds. According to Gertler and Gilchrist (1994), tightening monetary policy puts pressure on business investment decisions, now that the importance of money holdings which can timely 'rescue' companies from difficulties in external borrowing is more critical than ever. Moreover, this does not necessarily mean that, with expansionary monetary policy, the investment of the business depends only on external borrowing since the practice is bound to legal conditions. Especially, when the investment is not sufficient, the interest expense to be covered will increase the probability of bankruptcy. For this reason, the authors decided to study the sensitivity of investment to the internal cash flows of enterprises in Vietnam, comparing the differences in the sensitivity of enterprises with low and high financial constraints.

The State Bank of Vietnam is a unit of the state management apparatus. It is entitled to a monopoly in money issuing, performing the task of stabilizing the monetary value, establishing order, ensuring safe, stable, and effective operations with the aim of achieving the macroeconomic objectives of the state. To govern monetary policies, SBV must formulate and use its system of instruments, whose characteristics are to enable SBV to influence the predetermined factors for credit institutions to tailor their activities under the direction of SBV but still ensure their autonomy in business as well as the equality in the competitive environment among banks. There are four objectives of monetary policy: (i) to ensure economic growth, which is the most important and overarching purpose; (ii) to stabilize price and currency; (iii) to create employment and reduce the unemployment rate; (iv) to control the balance of payment. Therefore, the roles of the State Bank of Vietnam is significant in the transmission mechanism to corporates.

This paper will be conducted based on the following structure: Section 2 acknowledges the theoretical framework of monetary policies as well as internal cash flow on corporate investment. Then, Section 3 will briefly summarize the literature and empirical studies, which are relevant to the authors' research. In Section 4, methodology and research data will provide readers with the insights which the authors conducted. Afterwards, the authors discussed research findings and results in Section 5. Finally, the paper ends with conclusions and implications in Section 6.

\section{Theoretical Framework}

When it comes to the effect of monetary policies, we refer to Friedman (1978) theory about the crowd out theory. This theory means that the unsustainable and unclear in macroscopic policies can adversely trigger consequences such as higher inflation, or an increase of the interest rate in capital markets and vice versa. In brief, this phenomenon will be considered as a 'crowd out effect' of private sector borrowing as the study of Terjesen et al. (2016), Ayturk (2017). In addition, we also refer to Miller (1977) and Myers (1984) about the theoretical framework in two aspects (i) debt and taxes (ii) capital structure in corporates.

Originally initiated by Donaldson (1961), Pecking order theory was later developed by Myers and Majluf (1984), the theory starts with information asymmetry. When making investment decisions, corporations will always choose either the use of private capital or external financing. As a result, asymmetric information influences the choice between these two sources. According to the pecking order theory, private capital will be the priority in the investment decision, in which first comes the reinvested profits, then comes mobilized capitals through borrowings or debt-issuing (bonds). Issuance of new shares (stocks) is regarded as a last resort by this theory.

Before Q theory of (Grunfeld and Griliches 1960) is supposed to be the pioneer in using the market value of enterprises which represents the ability to generate expected returns and investment depends on the corporate's market value. Brainard and Tobin (1968), and Tobin (1969) had an idea to use Q 
index which stands for investment. The $Q$ index is calculated using either the ratio of market value of capital and replacement cost of capital or the ratio of market value and book value. According to $\mathrm{Q}$ theory, when the $\mathrm{Q}$ index is higher than one, corporate investment should be encouraged because if this is the case, the returns on investment are higher than the cost of buying corporate's assets. Conversely, corporate's investment should be discouraged if the $\mathrm{Q}$ index is lower than one due to the fact that the cost of buying assets is higher than the project's expected returns. According to Keynes (1936), investment can be determined by either aggregate demand or aggregate supply. This theory holds that the investor multiplier explains the relationship between an increase in investment and an increase in quantity, or, in other words, how an increase in investment affects quantity. From this perspective, investment appears to be a component of aggregate demand. From the perspective of aggregate supply, investment increases the quantity, which increases capital volumes, and promotes investment. This means that changes in quantity affect investment. As the demand for materials and labor increases, it is necessary to increase the number of products produced, leading to the need for more capital to invest in fixed assets in order to produce the number of products according to demand.

In brief, our study is mainly based on these essentially theoretical frameworks, which are mentioned carefully in this part. In Section 3, the authors will summarize the existing studies which are relevant to this research.

\section{Literature and Empirical Studies}

To begin, Tobias and Chiluwe (2012) used a number of classicist studies to explore how monetary policy impacts corporate investment. This research also refers to the enormous studies from Majumder (2007), Mishkin (2009), Kahn (2010), Bernanke and Gertler (1995). By employing macroeconomic data from 1996 to 2005, Tobias and Chiluwe (2012) concluded that the proportion of domestic debts and interest rates of the Ministry of Finance (MOF) was negatively related to the investment of private firms. Meanwhile, the money supply and savings do not show any statistical evidence on corporate investment. These studies provided fundamental concepts that microscopic factors are significant factors for corporate investment. Additionally, the expansion of monetary policies will positively influence corporate investment. To sum up, when money supply increases, interest rates fall. Finally, many companies are likely to attempt to finance their investments using external cashflows. That is the reason why Li and Liu (2017) and Morck et al. (2013) emphasized that the role of monetary policies on corporate financing sources is irreplaceble.

Recently, Yang et al. (2017) figured out that the tightened money supply from 2003 to 2013 made a corporate investment in China decrease. This policy also leads to the increase of cash holdings in Chinese firms. Interestingly, this study explicitly investigates the roles of institutional quality, ownership structure and financial development on the level of cash holding. There are many previous works done in terms of the efficiency of monetary policies such as Brandt and Li (2003), Carlino and DeFina (1998), as well as Devereux and Schiantarelli (1990). To be more precise, although the tightened monetary policy reduces investment, thanks to the use of cash holdings, corporates are still likely to be more active in their investments. Therefore, the role of cash holdings also supports the corporate activities in the context of tightened monetary policies. This motivates the authors to carry out further investigation into cash holdings as one of the controlling variables in this research.

When it comes to the internal cash flows, Fazzari et al. (1988) employed the dividend payout ratio as the identification variable for financial constraints. The study suggests that the dividend payout ratio is the measure of the availability of one of internal financing sources. Firms having the low dividend payouts are financially constrained while the ones with high dividend payouts are less financially constrained. In the research model, Fazzari et al. (1988) pointed out that firms which experience "financial constraints" are heavily dependent on internal cash flow. Therefore, it might lead to a decrease of investment in the future. In contrast, non-financially-constrained firms tend to expand their investments due to indifference between the externally and internally financing cost of capital. Therefore, these corporates are less dependent on cash flows. Once again, this empirical research 
encourages the authors to raise a question whether internal cash flows impact on investment decisions or corporate investments in Vietnam. Contradictorily, there are some studies which provide the opposite results with the work of Fazzari et al. (1988). For example, Kaplan and Zingales (1997) employed the sample having 49 firms over the period from 1970 to 1984 to test the investment activities in terms of cash-flow sensitivity. These authors combined relevant information and qualitative data to determine the availability of internal and external financial capital of the firms. Based on this, this research ranked the financial constraint level of each company per year. In conclusion, the results indicated that firms having less financially constrained features have higher investment cash flows than those in the counterparty group. Moreover, Kadapakkam et al. (1998) contributed an empirical result to the existing literature that internal cash flows and liquidity will forecast the future investment. These findings also pointed out that the sensitivity of investment activities is high in large firm group rather than the small ones. The following theoretical research from Almeida et al. (2004) also confirms these findings. Meanwhile, Richardson (2006) criticized that the dependence on internal cash flows might cause over-investment. Therefore, the authors inherited the previous studies to examine the role of internal cash flows in corporate investments in Vietnam. The authors acknowledge the various theoretical and empirical studies, which were conducted before such as Lamont (1997), Chen et al. (2016), Ahiadorme et al. (2018), etc. Furthermore, Devereux and Schiantarelli (1990) introduced how to classify the group of firms for testing the internal cash flow effects on firm investments. This study applied the method of market value of equity shares. Thus, the findings suggest that cash flows plays an important role in large companies than in small companies. Explaining this result, these authors asserted that large companies tend to have a relatively low cash balance and that these companies often have a large capital structure that increases representation costs. In addition, Athey and Laumas (1994) divided the sample of Indian firms by the book value of equity. These authors examined the importance of accelerated investment, internal funds, and depreciation for investment by manufacturing companies. The results indicate that internal funds and depreciation are significant in the accelerated investment model, but the relationship between internal and investment funds is not uniform among firms. In particular, internal funds and investment have a closer relationship in large companies and high-end manufacturing companies. Lastly, Vogt (1994) classified the US firms on the 'price-to-book ratio'. This classification shows that the companies having higher ratio experience the higher level of sensitivity, and vice versa. These empirical studies prove that internal financing sources have strong impacts on investment activities, regardless of firm size. Therefore, the authors would prefer to find out if the situation is different when it comes to Vietnam by measuring the levels of impact from the firm size perspective.

In brief, previous studies have explained the relationship between internal cash flow and firm investment through evidence of the existence of financial constraints. These studies explored inconclusive insights on the sensitivity of investment cash flows between low and high financially constrained groups. Noticeably, most studies also confirmed that there is an impact of internal cash flows on corporate investments with different signs and levels. Therefore, testing this phenomenon on Vietnamese equity market, which is considered as one of emerging markets in the world, is necessary to contribute to the existing studies. Our paper attempts to answer three main research questions: (i) Does the monetary policy influence on corporate investment in Vietnam? (ii) Is internal cash flow a factor which impacts on corporate investment in Vietnam? and (iii) Are there any differences between small and large groups in three main criteria regarding the influence of internal cash flows on corporate investments? These research questions will be answered in the Sections 5.1-5.3, respectively.

Hence, this paper will contribute to the existing literature in three main ways as follows. Firstly, this paper will provide the insights about the macroscopic determinant such as monetary policies on corporate investments. The purpose of this research is similar to the studies of Chang et al. (2018), Chen et al. (2018) and Zhao et al. (2018), which are up-to-date. Secondly, our paper offers the further novel and additional evidence on the relationship between microscopic factors such as internal cash flows and corporate investments. Thirdly, to complement to current studies, the authors classify the effects of internal cash flows according to three different sub-samples, namely (i) price-to-book ratio, 
(ii) net revenue, and (iii) total assets. Proposed by Devereux and Schiantarelli (1990), Vogt (1994), Allen et al. (2005), as well as Athey and Laumas (1994), respectively.

\section{Data and Methodology}

This research uses a sample of 250 Vietnamese firms with ten years from 2006 to 2016. The authors eliminate the firms, which have insufficient data as well as been delisted during their operation. Therefore, our sample can generalize the Vietnamese stock market. The chosen firms are all listed in the stock market, except financial firms, primary companies (banks and insurance companies), which had many values missing in the years to chosen to observe, individual firms, and particular transfer companies. The sample firms' financial information is collected from their financial reports, a reliable source.

Basically, Bond and Meghir (1994), Dickinson and Jia (2007) and Yang et al. (2017) introduced their research models, which explain the impact of supply of money on the corporate investment. Their models are rewritten as follows:

$$
\text { Invest }_{i, t}=\beta_{0}+\beta_{1} M P_{i, t}+\beta_{2} C F_{i, t}+\beta_{3 n} \sum_{1}^{t} \vec{Z}_{n, i, t-1}+\varepsilon_{i, t}
$$

In which, $i$ refers to sample firms and $t$ for a year, and $\varepsilon_{i, t}$ is the error term; $\beta$ stands for coefficients; Invest $_{i, t}$ is investment of $i$ th firm in year $t ; M P_{i, t}$ is referred to as money supply in year $\mathrm{t}$; $C F_{i, t}$ is referred to as ith firm's cash flow in year $t$. The authors denote the vector of $Z$ as a group of controlling variables such as S (firm size), Q (price-to-book ratio), LEV (financial leverage), ROA (return on asset), $\mathrm{T}$ (tangible asset over total asset), Growth (growth rate of revenue from business activities), NR (net revenue), and Cash (net cash holding).

Kadapakkam et al. (1998) also represented the research model hereinafter.

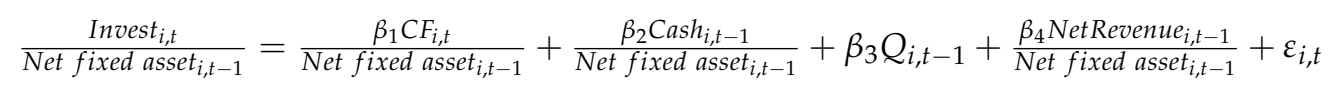

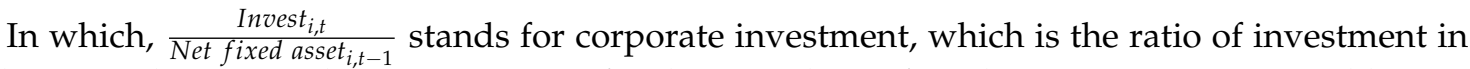
fixed asset in the year to the company's net fixed asset value, referred to as 'investment variable'.

$C F_{i, t}$ means the ability of the company to generate cash flow in a year, which is the ratio of cash flow in a year to the net fixed asset value at the beginning of that year, referred as 'cash flow variable'.

Cash $_{i, t-1}$ is the ratio of cash and cash equivalents at the beginning of the year to net fixed asset at the beginning of the year, referred to as 'cash holding variable'.

$Q_{i, t-1}$ is the value of $\mathrm{q}$ variable of Tobin at the beginning of the year, which is referred to as $Q$ variable.

$\frac{\text { NetRevenue }_{i, t-1}}{\text { Net fixed asset }}$ i,t-1 the ratio of net revenue of the previous year to the net fixed asset at the beginning of the year, which is referred to as revenue variable.

Finally, $\varepsilon_{i, t}$ is standard error.

The Table 1 demonstrates our variables, expected sign, explanation, calculation as well as literature review for using them.

This research used three indicators (i) price-to-book ratio, (ii) net revenue, and (iii) total assets to classify companies into two group: (a) large and (b) small by median of the total sample. Finally, the authors also construct to test our three main hypotheses as follows:

Hypothesis 1: The investments of Vietnamese firms increase when the State Bank of Vietnam promulgates the expansionary monetary policy.

Hypothesis 2: Internal cash flow affects the investment of Vietnamese firms. 
Hypothesis 3: The impacts of internal cash flows on investment vary according to business scale.

Table 1. Variables summary.

\begin{tabular}{|c|c|c|c|c|}
\hline Variables & Expected Sign & Explanation & Calculation & Literature Review \\
\hline $\begin{array}{l}\text { Invest } \\
\text { (Investment) }\end{array}$ & $\begin{array}{l}\text { Dependent } \\
\text { variable }\end{array}$ & $\begin{array}{l}\text { The additional } \\
\text { investment of facilities in } \\
\text { the company's fiscal year }\end{array}$ & $\begin{array}{l}\text { Invest = Net end-of-year } \\
\text { fixed assets }(-) \text { Net } \\
\text { worth of fixed assets at } \\
\text { the beginning of the year. }\end{array}$ & $\begin{array}{l}\text { Duchin et al. (2010) and } \\
\text { Kadapakkam et al. } \\
\text { (1998) }\end{array}$ \\
\hline $\begin{array}{l}\text { MP } \\
\text { (Monetary Policy) }\end{array}$ & $(+)$ & $\begin{array}{l}\text { The amount of central } \\
\text { bank supply money } \\
\text { under the expansionary } \\
\text { monetary policy }\end{array}$ & $\begin{array}{l}\text { The value of M2 supply } \\
\text { money }\end{array}$ & Li and Liu (2017) \\
\hline $\begin{array}{l}\text { LEV } \\
\text { (Leverage) }\end{array}$ & $(+)$ & $\begin{array}{l}\text { Corporate financial } \\
\text { leverage }\end{array}$ & $\begin{array}{l}\text { Total liabilities/total } \\
\text { assets }\end{array}$ & $\begin{array}{l}\text { Kaplan and Zingales } \\
\text { (1997), De Jong et al. } \\
\text { (2008) }\end{array}$ \\
\hline $\begin{array}{l}\text { SIZE } \\
\text { (Size) }\end{array}$ & $(-)$ & $\begin{array}{l}\text { The scale of the business } \\
\text { since listing on the stock } \\
\text { market }\end{array}$ & $\begin{array}{l}\text { The natural logarithm of } \\
\text { total assets }\end{array}$ & $\begin{array}{l}\text { Kaplan and Zingales } \\
\text { (1997) }\end{array}$ \\
\hline $\begin{array}{l}\text { ROA } \\
\text { (Return-on-Asset) }\end{array}$ & $(+/-)$ & Return on asset & Net profits/total assets & Yang et al. (2017) \\
\hline $\begin{array}{l}\text { Q } \\
\text { (Tobin-Q) }\end{array}$ & $(+)$ & $\begin{array}{l}\text { Q represents the growth } \\
\text { opportunities of } \\
\text { company. }\end{array}$ & $\begin{array}{l}\text { Tobin } Q=\text { market } \\
\text { value/book value }\end{array}$ & $\begin{array}{l}\text { Yang et al. (2017) and } \\
\text { Kadapakkam et al. } \\
(1998)\end{array}$ \\
\hline $\begin{array}{l}\mathrm{T} \\
\text { (Tangible Asset over } \\
\text { Total Asset) }\end{array}$ & $(+/-)$ & Asset structure & Fixed assets/total assets & Yang et al. (2017) \\
\hline Growth & $(+/-)$ & $\begin{array}{l}\text { Growth rate of operating } \\
\text { income }\end{array}$ & $\begin{array}{l}\text { Sale Ggrowth in year N/ } \\
\text { sale growth in year } \\
(\mathrm{N}-1)\end{array}$ & Yang et al. (2017) \\
\hline $\begin{array}{l}\text { CF } \\
\text { (Cash Flow) }\end{array}$ & $(+)$ & $\begin{array}{l}\text { Internal cash flow of } \\
\text { company }\end{array}$ & $\begin{array}{l}\text { CF is earning after tax }(+) \\
\text { fixed asset depreciation } \\
\text { in the year }(+) \text { corporate } \\
\text { income tax }(-) \text { dividend } \\
\text { payment. }\end{array}$ & $\begin{array}{l}\text { Kadapakkam et al. } \\
\text { (1998) }\end{array}$ \\
\hline Cash & $(+)$ & Cash holding & $\begin{array}{l}\text { Cash, deposits at banks, } \\
\text { and cash equivalents. }\end{array}$ & $\begin{array}{l}\text { Kadapakkam et al. } \\
\text { (1998) }\end{array}$ \\
\hline $\begin{array}{l}\text { NR } \\
\text { (Net Revenue) }\end{array}$ & $(+)$ & $\begin{array}{l}\text { Revenue from the sale of } \\
\text { goods and provision of } \\
\text { services minus }(-) \text { sales }\end{array}$ & $\begin{array}{l}\text { Revenue from sales and } \\
\text { service } \\
\text { provision-revenue } \\
\text { deductions }\end{array}$ & $\begin{array}{l}\text { Kadapakkam et al. } \\
\text { (1998) }\end{array}$ \\
\hline
\end{tabular}

In order to test these hypotheses, the authors briefly introduced the following regression models: The first model is to test the presence of monetary policy on firm investment (Hypothesis 1). This model is theoretically referred to Bond and Meghir (1994).

$$
\text { Invest }_{i, t}=\hat{\beta}_{0}+\hat{\beta}_{1} \mathrm{MP}_{\mathrm{i}, \mathrm{t}}+\hat{\beta}_{2} \mathrm{LEV}_{\mathrm{i}, \mathrm{t}}+\hat{\beta}_{3} \mathrm{~S}+\hat{\beta}_{4} \mathrm{ROA}+\hat{\beta}_{5} \mathrm{Q}+\hat{\beta}_{6} \mathrm{~T}+\hat{\beta}_{7} \text { Growth }+\hat{\varepsilon}_{\text {i.t. }}(\text { Model 1) }
$$

The second model is to test whether the internal cash flows influence the firm investment (Hypothesis 2). This model is theoretically referred to Kadapakkam et al. (1998).

$$
\text { Invest }_{i, t}=\hat{\beta}_{0}+\hat{\beta}_{1} C F_{i, t}+\hat{\beta}_{2} \operatorname{Cash}_{i, t}+\hat{\beta}_{3} Q+\hat{\beta}_{4} N R+\hat{\varepsilon}_{i . t}(\text { Model 2) }
$$

The third model is to test the differences in the impacts of internal cash flows on firm investment between two groups with three criteria (Hypothesis 3). The authors also employed model 2 but divided our sample into three sub-samples based on (i) price-to-book ratio, (ii) net revenue, and (iii) total assets. Afterward, the authors perform the individual regression for each group.

The authors employed the rich set of quantitative techniques namely pooled-ordinary least squares (pooled-OLS), fixed effect model, random effect model, and system-generalized method of moments (system-GMM) for this estimations. In order to enhance this paper methodological approach, the authors will briefly introduce the system-GMM procedure from Arellano and Bover (1995), and 
Blundell and Bond $(1998,2000)$. The econometric method of system-GMM introduces the pedagogic approach to linear regression for 'small-T and large- $\mathrm{N}$ ' (our samples have 10 years and 250 firms). Therefore, this methodology also confirms the use of instrumental variables to correct the endogeneity, which causes the biased and inconsistent results. Especially, system-GMM requires two-step robust estimation, which generates covariance matrix derived by Windmeijer (2005). Therefore, according to Maddala and Lahiri (1992) the results of system-GMM are robust for interpretation.

\section{Findings and Results}

This research is carried out by adopting the two main models:

Model 1: A study on the impacts of expansionary monetary policy on corporate investments.

Model 2: A study on the impacts of internal cash flows on corporate investments.

Firstly, the authors attempt to employ the statistical description for interpreting the data characteristics before performing regression.

As presented in Table 2, it is seen that the variables have the skewed and fat-tail distribution. This phenomenon might lead to the homogeneous characteristics, which probably causes endogeneity in these econometric models. Therefore, the authors bear in mind to adopt quantitative techniques, particularly system-GMM for correcting the bias and ensuring consistency.

Table 2. Statistical description of variables used for validation in the study.

\begin{tabular}{ccccccc}
\hline Variables & Mean & $\begin{array}{c}\text { Standard } \\
\text { Deviation }\end{array}$ & $\begin{array}{c}\text { Percentile } \\
\text { q10 }\end{array}$ & $\begin{array}{c}\text { Percentile } \\
\mathbf{q 9 0}\end{array}$ & Skewness & Kurtosis \\
\hline Invest & 73.275574 & 2828.286 & 0.0092945 & 0.406804 & 43.69604 & 2011.846 \\
MP & 112.1366 & 19.59663 & 93.65717 & 137.6491 & 0.4071207 & 2.540372 \\
S & 26.53337 & 5.002883 & 25.7329 & 29.111 & -4.737473 & 25.37874 \\
Q & 547.7386 & 20115.94 & 0.3380425 & 1.849735 & 37.41705 & 1410.435 \\
LEV & 0.4728379 & 0.2499534 & 0.112023 & 0.784358 & -0.1535366 & 2.201218 \\
ROA & 0.0665066 & 0.1375101 & -0.5436 & 0.1609 & 13.53076 & 336.1934 \\
T & 0.2551115 & 0.5036074 & 0.0116105 & 0.562433 & 35.59383 & 1611.327 \\
Growth & 0.7006606 & 26.70394 & -0.383467 & 0.987084 & 15.66164 & 1344.683 \\
NR & 180 & 0.496 & 105 & 342 & 8.22054 & 89.17907 \\
Cash & 406 & 0.952 & 254 & 372 & 51.50165 & 2682.775 \\
CF & -162 & 0.947 & -814 & 180 & 48.79517 & 2504.257 \\
\hline \multicolumn{7}{c}{ (Note that NR, Cash, and CF are million Vietnam dong). }
\end{tabular}

\subsection{First Hypothesis}

Table 3 presents the results of the regression model of the impacts of expansionary monetary policy on corporate investment (Model 1) by dependent variable (Invest) through four methodological approaches: pooled-OLS, FEM, REM, and GMM. The independent variables used to explain Invest (the investment variable) are MP (monetary policy), LEV (financial leverage), S (firm size), ROA (return on asset), Q (price-to-book ratio), $\mathrm{T}$ (tangible asset over total asset), Growth (growth rate of revenue from business activities), where MP is the primary explanatory variable and the most crucial one for this study.

Firstly, based on the pooled-OLS model, only the Q (price-to-book ratio) influences corporate investment at $1 \%$ significance level whereas there is no evidence about the relationship between monetary policies (the first hypothesis) on corporate investments. The remaining variables are insignificant. The authors suspect that there are endogeneous errors in this model. By employing the further quantitative techniques, namely fixed effect model and random effect model, the authors investigate that the results are not better. Once again, only $\mathrm{Q}$ (price-to-book ratio) is significant at $1 \%$ significance level while all explanatory variables fail to explain corporate investments. Hence, the authors implement the system-GMM for estimating Model 1 equation and afterwards, the results are documented in the last column in Table 2 above. 
Table 3. Results of the regression model of the impact of monetary expansion policy on corporate investment (Model 1).

\begin{tabular}{|c|c|c|c|c|}
\hline \multirow[b]{2}{*}{ Invest } & \multicolumn{4}{|c|}{ Invest $_{i, t}=\hat{\beta}_{0}+\hat{\beta}_{1}$ MP $_{\mathbf{i}, t}+\hat{\beta}_{2} L_{E V} V_{i, t}+\hat{\beta}_{3} S+\hat{\beta}_{4} R O A+\hat{\beta}_{5} R O A+\hat{\beta}_{6} Q+\hat{\beta}_{7} T+\hat{\beta}_{8}$ Growth $+\hat{\varepsilon}_{i . t}$} \\
\hline & Pooled OLS & $\begin{array}{c}\text { FEM (Fixed } \\
\text { Effects Model) }\end{array}$ & $\begin{array}{l}\text { REM (Random } \\
\text { Effects Model) }\end{array}$ & $\begin{array}{c}\text { System GMM (Generalized } \\
\text { Method of Moments) }\end{array}$ \\
\hline MP & $\begin{array}{c}-0.5711737 \\
{[-0.67]}\end{array}$ & $\begin{array}{c}-0.6836043 \\
{[0.451]}\end{array}$ & $\begin{array}{c}-0.5711737 \\
{[0.504]}\end{array}$ & $\begin{array}{c}0.8546331 * \\
{[0.058]}\end{array}$ \\
\hline Lev & $\begin{array}{c}-34.25557 \\
{[0.625]}\end{array}$ & $\begin{array}{c}-110.0149 \\
{[0.348]}\end{array}$ & $\begin{array}{c}-34.25557 \\
{[0.625]}\end{array}$ & $\begin{array}{c}49.69802 * \\
{[0.087]}\end{array}$ \\
\hline $\mathbf{S}$ & $\begin{array}{c}1.699131 \\
{[0.645]}\end{array}$ & $\begin{array}{c}3.657795 \\
{[0.419]}\end{array}$ & $\begin{array}{c}1.699131 \\
{[0.645]}\end{array}$ & $\begin{array}{c}-13.69331 \text { ** } \\
{[0.018]}\end{array}$ \\
\hline ROA & $\begin{array}{c}-0.7834284 \\
{[0.995]}\end{array}$ & $\begin{array}{c}6.300236 \\
{[0.964]}\end{array}$ & $\begin{array}{c}-0.7834284 \\
{[0.995]}\end{array}$ & $\begin{array}{l}51.8322 \\
{[0.385]}\end{array}$ \\
\hline Q & $\begin{array}{c}0.13454811^{* * *} \\
{[0.000]}\end{array}$ & $\begin{array}{c}0.1353923 * * * \\
{[0.000]}\end{array}$ & $\begin{array}{c}0.1345481 * * * \\
{[0.000]}\end{array}$ & $\begin{array}{c}0.1687338^{* * *} \\
{[0.000]}\end{array}$ \\
\hline $\mathbf{T}$ & $\begin{array}{c}-1.27182 \\
{[0.968]}\end{array}$ & $\begin{array}{c}-2.928004 \\
{[0.936]}\end{array}$ & $\begin{array}{c}-1.27182 \\
{[0.968]}\end{array}$ & $\begin{array}{c}-17.29324 \\
{[0.352]}\end{array}$ \\
\hline Growth & $\begin{array}{c}-0.0058518 \\
{[0.992]}\end{array}$ & $\begin{array}{c}-0.2729514 \\
{[0.675]}\end{array}$ & $\begin{array}{c}-0.0058518 \\
{[0.992]}\end{array}$ & $\begin{array}{c}-0.3502424 \\
{[0.198]}\end{array}$ \\
\hline Cons & 0.748 & 0.791 & 0.748 & 0.044 \\
\hline AR(1) & & & & 0.000 \\
\hline $\operatorname{AR}(2)$ & & & & 0.231 \\
\hline Sargan test & & & & 0.376 \\
\hline
\end{tabular}

Secondly, the findings are similar to the previous studies of Tobias and Chiluwe (2012), Majumder (2007), Mishkin (2009), Kahn (2010), and Bernanke and Gertler (1995) in many different countries. The monetary policies have positive influences corporate investments. However, this is weak evidence because its coefficient is significant at 10\% significance level. In other words, when SBV promulgates expansionary monetary policy, corporate investment will increase. Thus, the result fails to reject the first hypothesis.

When it comes to the other variables, Lev (financial leverage) also shows a weak evidence of its impacts on corporate investments. When Vietnamese companies choose to increase their financial leverage, they tend to obtain new investment at 10\% significance level. To be more specific, the stronger the financial leverage, the higher the investment. Interestingly, the $S$ (firm size) has a negative coefficient, which means that the larger firms might have fewer investments. In addition, the $Q$ (price-to-book ratio) significantly affects the firm investments. This means that the market value has a strong impact on corporate investment. As companies have greater market value, they will increasingly promote their investments. The other variables, namely ROA (return on asset), $\mathrm{T}$ (tangible asset over total asset), Growth (growth rate of revenue from business activities) have no statistical evidence to come into conclusion.

Finally, the authors also need to confirm that the findings and results are unbiased and robust. The further tests of $\operatorname{AR}(1), A R(2)$, as well as Sargan test are appropriate. To be more specific, the authors fail to reject the null of hypothesis that instrumental variables have no correlation with the residuals. Moreover, the errors in the first-differenced regression do not demonstrate the second-order serial correlation. To sum up, the results and findings are worth to interpret. These results are appropriately used to answer the first research question that monetary policy influences corporate investment.

However, to be sure whether the multicollinearity errors among the variables exists, the authors perform the Variance Inflation Factor (VIF) test for the model, see Table 4.

The result of the VIF test shows that all the VIF coefficients are less than 10. This explains that the multi-collinear phenomenon did not occur in the research set (Kennedy 1992). 
Table 4. Multicollinearity verification in model 2.

\begin{tabular}{ccc}
\hline Variable & VIF & 1/VIF \\
\hline Net & 1.01 & 0.986199 \\
CF & 1.01 & 0.988369 \\
Cash & 1.00 & 0.997063 \\
Q & 1.00 & 0.999537 \\
\hline
\end{tabular}

\subsection{Second Hypothesis}

When it comes to Model 2, the results of regression on the impacts of cash flow on investment with the dependent variable investment (Invest) through four models: pooled-OLS, FEM, REM, and system-GMM. The independent variables that are used to explain the investing variable are CF (cash flow), Cash (cash holding), Q (price-to-book ratio), and NR (net revenue). There is no evidence of model errors such as multicollinearity, autocorrelation as well as heteroscedasticity. Therefore, the model with pooled-OLS, FEM, REM, and GMM are statistically employed to test the second hypothesis. Firstly, based on the pooled-OLS model, the $\mathrm{Q}$ (price-to-book ratio) is only determinant of corporate investments at $1 \%$ significance level. However, the remaining variables show no statistical evidence at any significance level. The findings are the same for fixed effect model and random effect model. To be more specific, once again, only $Q$ (price-to-book ratio) is significant at $1 \%$ significance level while all explanatory variables fail to explain the corporate investments at the two econometrical approaches. Hence, using system-GMM to correct the endogenous errors (Model 2). Finally, the coefficients and t-statistics are noted in the Table 5 below.

Table 5. Regression results on the impact of internal cash flow on investment (Model 2).

\begin{tabular}{|c|c|c|c|c|}
\hline \multirow{2}{*}{ Invest } & \multicolumn{4}{|c|}{ Invest $_{i, t}=\hat{\beta}_{0}+\hat{\beta}_{1} C F_{i, t}+\hat{\beta}_{2} \operatorname{Cash}_{i, t}+\hat{\beta}_{3} Q+\hat{\beta}_{4} N R+\hat{\varepsilon}_{i . t}$} \\
\hline & Pooled OLS & FEM & REM & System GMM \\
\hline \multirow[t]{2}{*}{$\mathrm{CF}$} & $5.47^{\text {(a) }}$ & $6.28^{(a)}$ & $5.47^{(\mathrm{a})}$ & $939^{\text {(a) } * * *}$ \\
\hline & [0.7495] & {$[0.743]$} & [0.749] & {$[0.006]$} \\
\hline \multirow[t]{2}{*}{ Cash } & $-0.03 .14^{(\mathrm{a})}$ & $0.747^{(a)}$ & $-0.0314^{(a)}$ & $99.5^{(\mathrm{a})}$ \\
\hline & [0.999] & [0.969] & [0.999] & {$[0.668]$} \\
\hline \multirow[t]{2}{*}{$\mathrm{Q}$} & $0.1345012^{* * *}$ & $0.1353395^{* * *}$ & $0.1345012^{* * *}$ & $0.1354203^{* * *}$ \\
\hline & [0.000] & [0.000] & [0.000] & {$[0.000]$} \\
\hline \multirow[t]{2}{*}{ NR } & $5.33^{(a)}$ & $8.60^{\text {(a) }}$ & $5.33^{(a)}$ & $0.0517^{(\mathrm{a})} * *$ \\
\hline & [0.874] & {$[0.856]$} & {$[0.874]$} & {$[0.023]$} \\
\hline Cons & 0.748 & 0.903 & 0.942 & 0.072 \\
\hline $\operatorname{AR}(1)$ & & & & 0.000 \\
\hline $\mathrm{AR}(2)$ & & & & 0.998 \\
\hline Sargan test & & & & 0.865 \\
\hline
\end{tabular}

The $\operatorname{symbols}^{*}, * *$, and ${ }^{* * *}$ denote the significance at the 10,5 , and $1 \%$ levels, respectively whereas $t$-statistics of the corresponding coefficients are reflected in square brackets. The Sargan test is a Sargan-Hansen test of over-identifying restrictions. $\mathrm{AR}(1)$ and $\mathrm{AR}(2)$ are tests for first and second-order serial correlation in the first-differenced residuals. Note that ${ }^{(a)}$ means that the multiple of $10^{-13}$.

As regards the system-GMM, internal cash flow has positively influenced corporate investments. Especially, this demonstrates a strong evidence because its coefficient is significant at $1 \%$ significance level. The greater the internal cash flow, the larger the corporate investment values. Hence, the result, once again, fails to reject the second hypothesis. In the context of other variables, the results share same patterns with the previous study of Kadapakkam et al. (1998). To be more specific, the Q (price-to-book ratio) influences corporate investment at 1\% significance level. Furthermore, the NR (net revenue) significantly affects the corporate investments at $5 \%$ significance level. Unexpectedly, cash is insignificant in this regression estimations. This shows that corporate investment is not sensitive to internal cash flow in Vietnam. Meanwhile, the firms having greater net revenue are likely to invest more. The first-order and second-order correlation in the estimations showed that the results are robust. Furthermore, the Sargan-Hansen test also indicates that the instrumental variables are not correlated 
with the residuals. Once again, the results are unbiased and consistent. Therefore, the second research question is answered, which means that the internal cash flow also affect the corporate investment in Vietnam.

\subsection{Third Hypothesis}

By dividing the samples into two groups (i) small and (ii) large based on three criteria: (i) price-to-book ratio, (ii) net revenue, and (iii) total assets, the authors examine the scale effect of internal cash flow on corporate investment. The Table 5 demonstrates the results of pooled-OLS regression of model 2 by two sub-samples dividing by price-to-book ratio. The main reason for choosing pooled-OLS is to reexamine the sub-sample effects between the two groups. The previous results and findings are robust because of system-GMM techniques; therefore, the authors only employ the simple rule in statistics (known as parsimony) for testing the third hypothesis.

As can be seen from Table 6, the $Q$ (price-to-book ratio) in the large group is significant at $1 \%$ significance level for the three criteria. In addition, there is a weak evidence that internal cash flow influences corporate investments in the large group at the sub-sample of $Q$ (price-to-book ratio). Therefore, the authors fail to reject the third hypothesis. This proves that there are differences in the impacts of internal cash flow on corporate investment. Internal cash flows in large-scale firms have a weak impact on corporate investment, suggesting that financial constraint issues and asymmetric information do not affect the investment decisions of small-scale firms. Large-scale firms are more cautious in investing, not only in external capital but also in internal cash flow and the amount of money they hold to decide whether to increase the investment or not. The findings and results are similar to the study of Kaplan and Zingales (1997). Thus, there are differences between two sub-samples concerning the impacts of internal cash flow on corporate investment, which is the third research answer.

Table 6. Summary regression results by sub-samples based on three criteria by pooled-OLS.

\begin{tabular}{|c|c|c|}
\hline \multirow{2}{*}{ Variable } & \multicolumn{2}{|c|}{ Price-to-Book Ratio } \\
\hline & Small & Large \\
\hline $\mathrm{CF}$ & $\begin{array}{c}0.000322^{(a)} \\
{[0.02]}\end{array}$ & $\begin{array}{l}371^{(a)} \\
{[1.87]}\end{array}$ \\
\hline Cash & $\begin{array}{c}-0.00398 \text { (a) } \\
{[-0.22]}\end{array}$ & $\begin{array}{l}487 \text { (a) } \\
{[1.27]}\end{array}$ \\
\hline $\mathrm{Q}$ & $\begin{array}{c}-0.0865233 \\
{[-1.21]}\end{array}$ & $\begin{array}{c}0.1348381 \text { *** } \\
{[119.71]}\end{array}$ \\
\hline NR & $\begin{array}{c}-0.0587^{(\mathrm{a})} \\
{[-0.75]}\end{array}$ & $\begin{array}{l}226^{(a)} \\
{[0.35]}\end{array}$ \\
\hline Cons & $\begin{array}{c}0.3279273 \\
{[5.11]}\end{array}$ & $\begin{array}{c}-2.675934 \\
{[-0.08]}\end{array}$ \\
\hline \multirow{2}{*}{ Variable } & \multicolumn{2}{|c|}{ Net revenue } \\
\hline & Small & Large \\
\hline $\mathrm{CF}$ & $\begin{array}{c}0.04^{(a)} \\
{[0.11]}\end{array}$ & $\begin{array}{c}5.44^{\text {(a) }} \\
{[0.22]}\end{array}$ \\
\hline Cash & $\begin{array}{c}-4690^{(a)} \\
{[-0.20]}\end{array}$ & $\begin{array}{l}-9.07^{(a)} \\
{[-0.03]}\end{array}$ \\
\hline Q & $\begin{array}{c}-0.0169778 \\
{[-0.58]}\end{array}$ & $\begin{array}{c}0.1345023 \text { *** } \\
{[118.90]}\end{array}$ \\
\hline NR & $\begin{array}{l}-10.4^{(a)} \\
{[-0.90]}\end{array}$ & $\begin{array}{c}7.59^{\text {(a) }} \\
{[0.12]}\end{array}$ \\
\hline Cons & $\begin{array}{c}0.3017064 \\
{[6.64]}\end{array}$ & $\begin{array}{c}-2.256631 \\
{[-0.06]}\end{array}$ \\
\hline
\end{tabular}


Table 6. Cont.

\begin{tabular}{|c|c|c|}
\hline \multirow{2}{*}{ Variable } & \multicolumn{2}{|c|}{ Price-to-Book Ratio } \\
\hline & Small & Large \\
\hline \multirow{2}{*}{ Variable } & \multicolumn{2}{|c|}{ Total asset } \\
\hline & Small & Large \\
\hline $\mathrm{CF}$ & $\begin{array}{c}-2460^{(a)} \\
{[-0.10]}\end{array}$ & $\begin{array}{l}292^{\text {(a) }} \\
{[1.63]}\end{array}$ \\
\hline Cash & $\begin{array}{c}-5310^{(\mathrm{a})} \\
{[-0.21]}\end{array}$ & $\begin{array}{c}3.57^{\text {(a) }} \\
{[1.00]}\end{array}$ \\
\hline Q & $\begin{array}{c}0.0195474 \\
{[0.62]}\end{array}$ & $\begin{array}{c}0.1347637^{* * *} \\
{[118.10]}\end{array}$ \\
\hline NR & $\begin{array}{c}-0.0546^{(\mathrm{a})} \\
{[-0.52]}\end{array}$ & $\begin{array}{c}26.9^{(\mathrm{a})} \\
{[0.41]}\end{array}$ \\
\hline Cons & $\begin{array}{c}0.3123523 \\
{[6.37]}\end{array}$ & $\begin{array}{c}-1.486654 \\
{[-0.04]}\end{array}$ \\
\hline
\end{tabular}

The symbols ***, and ${ }^{* * *}$ denote the significance at the 10,5 , and $1 \%$ levels, respectively whereas $t$-statistics of the corresponding coefficients are reflected in square brackets. Note that ${ }^{(\mathrm{a})}$ means that the multiple of $10^{-13}$.

\section{Conclusions and Implications}

\subsection{Conclusions}

By employing the rich set of quantitative techniques, the authors confirm that when the State Bank of Vietnam promulgates expansionary monetary policies, corporate investments increase. This explains why corporate investment is heavily dependent on external sources of capital. With the expansionary monetary policy, which means lower interest rates, businesses will tend to borrow and invest more and more. Obviously, borrowing for investment when commercial banks apply an expansionary monetary policy is ideal because interest expense is no longer too heavy. It also creates opportunity cost for shareholders to invest in many other fields instead of retaining profits to continue investing in fixed assets. On top of that, interest rates is a great tax shield for businesses. However, it is very interesting to witness that the monetary policy effect is quite weak. Therefore, apart from macroeconomic elements, corporate investment is also affected by the internal elements. To prove that, the authors have implemented further research on the impacts of internal cash flow on corporate investment. At the same time, cash holdings, market value, and net revenue are also considered in this study to explain corporate investments.

As the expectation of the theoretical research of Kaplan and Zingales (1997), internal capital flows have a significant impact on corporate investment. It can be interpreted that the more effective the business is, the more investment in fixed assets it can attract to expand the scale of business. Investigating an impact of internal cash flow on investment helps practitioners recognize that market value plays an important role in corporate investment decisions. In addition, the classification of the scale of business has shown that large-scale groups are more sensitive to internal cash flows than small-scale ones. Moreover, research results from both groups of companies show that cash holdings does not affect the investment decisions of enterprises. However, with different scale groups, research results found that cash holdings play an extremely important role in large-scale enterprise groups. Thereby, it shows that large enterprises are very careful in making investment decisions and allocating capital.

\subsection{Implications}

By the two main research models, the authors also conclude that both macroeconomic and internal factors always influence corporate investment. In particular, the macroeconomic factors are the most important and decisive factors. Monetary policy plays a vital role in the economy. The study demonstrates that expansionary monetary policy makes investment increases. However, it is 
not always true in the case that monetary policy is ideal as the more the inflation increases, the more the real value of the currency decreases. Also, the dependence on external financing of businesses is growing, and interest rates increase the risk of bankruptcy and lousy debts more and more. The study does not aim to promote expansionary monetary policy but to measure the degree and direction of impacts on investment. Based on that, SBV can consider in combination with the socio-economic situations to best-tailor the monetary policy.

Dependence on external financing of small business is understandable. However, small-business groups need to focus on the role of cash holdings in an investment in order to minimize the risks of interest and react timely to the economy as soon as the market fluctuates. The evolution of the economy is like a parabolic graph: growth and recession will take place from time to time, and this is indispensable. Therefore, the preparation to respond to the fluctuations is very important to help businesses survive and develop.

As regards the macroscopic aspects, the study must carry out in-depth research on each group of companies in order to have the most general overview of the problem. Especially, with an emerging economy like Vietnam, in which most of the businesses are small and medium, the research groups are the businesses that are listed on the stock exchange and all of which are well positioned in the Vietnamese economy. Therefore, the study cannot cover all enterprises with financial constraints, especially those in rural areas and underprivileged economic areas.

From the limitations of the research, the authors propose separate research on how monetary policy affects investment. The sample should be expanded to more enterprises and consider the impacts on each group of enterprises: large-scale, medium scale enterprises, small-scale enterprises, and enterprises with financial constraints (small enterprises, rural enterprises, etc.). Because this is a macro issue, further research should be more intensive and in-depth.

As regards the recommendations for monetary authority, the authors suggest that State Bank of Vietnam should remain the sustainable monetary policy. Any change in monetary policy should be carefully considered in the economic and political aspects. Furthermore, holding the expansionary monetary policies will encourage corporate investments; however, it also has to pay the prices for 'inflation'. This research suggests the further quantitative techniques to estimate the threshold of the M2 money supply to be optimal for Vietnamese economy.

The authors suggest researching the importance of cash holdings in businesses. Because the authors focus on the impacts of internal cash flow on investment, so cash is only a second variable and fail to be able to go into the problem. Investigating the role of cash holdings in investment is extremely necessary. However, in Vietnam, such studies do not receive as much proper attention as in European countries as well as in the US. In China, there has recently been many topics related to the topic of cash holdings in the business. The authors strongly believe that more studies as well as discussions will be held on this topic in Vietnam in the future.

Author Contributions: These authors contributed equally to this work.

Funding: This research was funded by University of Economics Ho Chi Minh City (Vietnam), Banking University of Ho Chi Minh City (Vietnam) and Foreign Trade University (Vietnam).

Acknowledgments: We are grateful for the anonymous referees for their remarks. Any remaining errors are our own responsibilities. The first author would also like to thank Bui Cong Duy (Banking University of Ho Chi Minh City) and Nguyen Thi Thu Hien (Institute of Banking Research and Technology, Banking University of Ho Chi Minh City) for their continuous guidance and encouragement. This paper was presented in the National Olympic Contest of Econometrics and Applications held by Academy of Finance (Vietnam) in 2018. The work is the outcome of the research group by Student Research Group (Banking University of Ho Chi Minh City) and Vietnamese Students' Association at Banking University of Ho Chi Minh City (Vietnam).

Conflicts of Interest: These authors confirm that there are no conflict of interest. 


\section{References}

Ahiadorme, Johnson Worlanyo, Agyapomaa Gyeke-Dako, and Joshua Yindenaba Abor. 2018. Debt holdings and investment cash flow sensitivity of listed firms. International Journal of Emerging Markets 13: 943-58. [CrossRef]

Allen, Franklin, Jun Qian, and Meijun Qian. 2005. Law, finance and economic growth in China. Journal of Financial Economics 77: 57-116. [CrossRef]

Almeida, Heitor, Murillo Campello, and Michael S. Weisbach. 2004. The cash flow sensitivity of cash. The Journal of Finance 59: 1777-804. [CrossRef]

Arellano, Manuel, and Olympia Bover. 1995. Another look at the instrumental variable estimation of error-components models. Journal of Econometrics 68: 29-51. [CrossRef]

Athey, Michael J., and Prem S. Laumas. 1994. Internal funds and corporate investment in India. Journal of Development Economics 45: 287-303. [CrossRef]

Ayturk, Yusuf. 2017. The effects of government borrowing on corporate financing: Evidence from Europe. Finance Research Letters 20: 96-103. [CrossRef]

Batten, Jonathan A., and Xuan Vinh Vo. 2014. Liquidity and Return Relationships in an Emerging Market. Emerging Markets Finance and Trade 50: 5-21. [CrossRef]

Batten, Jonathan A., and Xuan Vinh Vo. 2015. Foreign ownership in emerging stock markets. Journal of Multinational Financial Management 32-33: 15-24. [CrossRef]

Bernanke, Ben S., and Mark Gertler. 1995. Inside the black box: the credit channel of monetary policy transmission. Journal of Economic perspectives 9: 27-48. [CrossRef]

Bloomberg. 2016. Vietnam's Economy Is an Emerging Market Standout. Available online: https: / / www.bloomberg.com/news/articles/2016-01-18/vietnam-growth-makes-it-emerging-marketstandout-in-shaky-world (accessed on 7 February 2017).

Blundell, Richard, and Stephen Bond. 1998. Initial conditions and moment restrictions in dynamic panel data models. Journal of Econometrics 87: 115-43. [CrossRef]

Blundell, Richard, and Stephen Bond. 2000. GMM estimation with persistent panel data: An application to production functions. Econometric Reviews 19: 321-40. [CrossRef]

Bond, Stephen, and Costas Meghir. 1994. Dynamic investment models and the firm's financial policy. The Review of Economic Studies 61: 197-222. [CrossRef]

Brainard, William C., and James Tobin. 1968. Pitfalls in financial model building. The American Economic Review 58: 99-122.

Brandt, Loren, and Hongbin Li. 2003. Bank discrimination in transition economies: Ideology, information, or incentives? Journal of Comparative Economics 31: 387-413. [CrossRef]

Carlino, Gerald, and Robert DeFina. 1998. The differential regional effects of monetary policy. Review of Economics and Statistics 80: 572-87. [CrossRef]

Chang, Chun, Zheng Liu, Mark M. Spiegel, and Jingyi Zhang. 2018. Reserve requirements and optimal chinese stabilization policy. Journal of Monetary Economics. [CrossRef]

Chen, Xin, Yong Sun, and Xiaodong Xu. 2016. Free cash flow, over-investment and corporate governance in China. Pacific-Basin Finance Journal 37: 81-103. [CrossRef]

Chen, Kaiji, Jue Ren, and Tao Zha. 2018. The nexus of monetary policy and shadow banking in China. American Economic Review 108: 3891-936. [CrossRef]

De Jong, Abe, Rezaul Kabir, and Thuy Thu Nguyen. 2008. Capital structure around the world: The roles of firm-and country-specific determinants. Journal of Banking \& Finance 32: 1954-69.

Devereux, Michael, and Fabio Schiantarelli. 1990. Investment, Finacial Factors and Cash Flow: Evidence from UK Panel Data (No. w3116). Cambridge: National Bureau of Economic Research.

Dickinson, David, and Liu Jia. 2007. The real effects of monetary policy in China: An empirical analysis. China Economic Review 18: 87-111. [CrossRef]

Donaldson, Gordon. 1961. Corporate Debt Capacity. Cambridge: Harvard University Press.

Duchin, Ran, Oguzhan Ozbas, and Beck A. Sensoy. 2010. Costly external finance, corporate investment, and the subprime mortgage credit crisis. Journal of Finance Economics 97: 418-35. [CrossRef]

Fazzari, Steven, R. Glenn Hubbard, and Bruce C. Petersen. 1988. Financing constraints and corporate investment. Brookings Papers on Economic Activity I 1988: 141-206. [CrossRef] 
Friedman, Benjamin M. 1978. Crowding out or Crowding in? The Economic Consequences of Financing Government Deficits. Cambridge: National Bureau of Economic Research.

Gertler, Mark, and Simon Gilchrist. 1994. Monetary policy, business cycles, and the behavior of small manufacturing firms. The Quarterly Journal of Economics 109: 309-40. [CrossRef]

Grunfeld, Yehuda, and Zvi Griliches. 1960. Is aggregation necessarily bad? The Review of Economics and Statistics 42: 1-13. [CrossRef]

Kadapakkam, Palani-Rajan, P. C. Kumar, and Leigh A. Riddick. 1998. The impact of cash flows and firm size on investment: 'The international evidence'. Journal of Banking \& Finance 22: 293-320.

Kahn, George A. 2010. Monetary policy under a corridor operating framework. Economic Review (Kansas City) 95: 5-35.

Kaplan, Steven N., and Luigi Zingales. 1997. Do investment-cash flow sensitivities provide useful measures of financing constraints? The Quarterly Journal of Economics 112: 169-215. [CrossRef]

Kashyap, Anil K., Jeremy C. Stein, and David W. Wilcox. 1993. The monetary transmission mechanism: Evidence from the composition of external finance. American Economic Review 83: 78-98.

Kennedy, Peter. 1992. A Guide to Econometrics, 3rd ed. Cambridge: The MIT Press.

Keynes, John Maynard. 1936. The General Theory of Employment. Interest and Money. London: Palgrave Macmillan, Cambridge: Cambridge University Press, for Royal Economic Society.

Lamont, Owen. 1997. Cash flow and investment: 'Evidence from internal capital markets'. Journal of Finance 52: 83-109. [CrossRef]

Li, Bing, and Qing Liu. 2017. On the choice of monetary policy rules for China: A Bayesian DSGE approach. China Economic Review 44: 166-85. [CrossRef]

Maddala, Gangadharrao S., and Kajal Lahiri. 1992. Introduction to Econometrics. New York: Macmillan, vol. 2.

Majumder, Alauddin. 2007. Does Public Borrowing Crowd-out Private Investment? The Bangladesh Evidence. Policy Analysis Unit Working Paper Series 708.

Myers, Stewart C., and Nicholas S. Majluf. 1984. Corporate financing and investment decisions when firms have information that investors do not have. Journal of Financial Economics 13: 187-221. [CrossRef]

Miller, Merton H. 1977. Debt and taxes. The Journal of Finance 32: 261-75.

Mishkin, Frederic S. 2009. Will monetary policy become more of a science? In Monetary Policy Over Fifty Years. Abingdon: Routledge, pp. 93-119.

Morck, Randall, M. Deniz Yavuz, and Bernard Yeung. 2013. State-Controlled Banks and the Effectiveness of Monetary Policy. Cambridge: National Bureau of Economic Research.

Myers, Stewart C. 1984. The capital structure puzzle. The Journal of Finance 39: 574-92. [CrossRef]

Richardson, Scott. 2006. Over-investment of free cash flow. Review of Accounting Studies 11: 159-89. [CrossRef]

Terjesen, Siri, Niels Bosma, and Erik Stam. 2016. Advancing public policy for high-growth, female, and social entrepreneurs. Public Administration Review 76: 230-39. [CrossRef]

Tobias, Olweny, and Mambo Chiluwe. 2012. The effect of monetary policy on private sector investment in Kenya. Journal of Applied Finance and Banking 2: 239.

Tobin, James. 1969. A general equilibrium approach to monetary theory. Journal of Money, Credit and Banking 1: 15-29. [CrossRef]

Vogt, Stephen C. 1994. The cash flow/investment relationship: 'Evidence from US manufacturing firms'. Financial Management 23: 3-20. [CrossRef]

Windmeijer, Frank. 2005. A finite sample correction for the variance of linear efficient two-step GMM estimators. Journal of Econometrics 126: 25-51. [CrossRef]

Yang, Xingquan, Liang Han, Wanli Li, Xingqiang Yin, and Lin Tian. 2017. Monetary policy, cash holding and corporate investment: 'Evidence from China'. China Economic Review 46: 110-22. [CrossRef]

Zhao, Jing, Xiao Chen, and Ying Hao. 2018. Monetary policy, government control and capital investment: Evidence from China. China Journal of Accounting Research 11: 233-54. [CrossRef]

(C) 2019 by the authors. Licensee MDPI, Basel, Switzerland. This article is an open access article distributed under the terms and conditions of the Creative Commons Attribution (CC BY) license (http:/ / creativecommons.org/licenses/by/4.0/). 